\title{
Iz Senekovega Ojdipa
}

Nekromantija (530-658)

\section{Prevedel Brane Senegačnik}

Kreont

Od mesta daleč stran črni se cerov gaj,

nekje v bližini vodnate doline Dirke.

Cipresa vrh svoj dviga nad visoki gozd,

telo, zeleno zmeraj, v iglic plašč zavija;

Star hrast tam steza grčave in trhle veje:

požrešni čas razjedel mu je eno stran

a druge padec bližnje deblo je prestreglo,

na njem visi zdaj s korenino preperelo.

Tam lovor z grenkim plodom je, lahkotne lipe

in mirta pafijska in jelša, ki bo vesla

pognala čez brezmejno morje; jelka k Fojbu

se z gladkim deblom vzpenja, kljubujoč zefirjem.

Na sredi je drevo neznansko: težko senco

na nižje rastje meče daleč naokrog;

$z$ vejevjem silnim samo brani ves ta gozd.

Zlovešča voda, ki ne ve za sončno luč,

pod njim mezi in v večnem hladu zdreveneva;

močvirje glenasto obkroža leni izvir.

Ko sem prispel je stari svečenik, ni čakal:

ta kraj temine nočne sam je priskrbel.

Skopali jamo so in vanjo vrgli ogorke,

iztrgane iz grmad nagrobnih; vedež pa,

v mrtvaškem ogrinjalu $z$ vejo zamahuje.

Do tal se mu razliva žalno oblačilo,

$\mathrm{v}$ srhljivi opravi stopa temni starec $\mathrm{z}$ vencem 
iz smrtonosne tise okoli belih las.

Goveda črna, temnoruna jagnjeta

k oltarju vlečejo za rep: že pleni plamen

si živo žrtev, ki se v smrtnem ognju zvija.

Zdaj kliče mrtve; tebe, ki jim vladaš;

in njega, ki stražari pot čez vodo Lete.

In čarni rek preteč ponavlja, ustnice

mu kremži bes, ko poje to, kar sence lahke

zmiri ali obvlada. Kri na žrtvenike

izliva, ovce cele žge in polni jamo

s krvavim pitjem. Snežno mleko zliva čezenj,

in $\mathrm{z}$ levo roko Bakhov pitni dar dodaja

in spet ponavlja pesem $s$ težjim, blaznim glasom,

z očmi, zadrtimi v tla, umrle kliče.

Zalajal je Hekatin trop: in trikrat jamo

tegoben stok pretrese, iz globin vzdrhti

vsa zemlja. »Uslišan sem«, je rekel svečenik.

»Besede prave! Zdaj se trga slepi Kaos

in ljudstvom Dita odpira pot na zgornji svet."

Uskoči se ves gozd in listje naježi se,

razlamljajo se hrasti, groza stresa gaj,

izmika zemlja se, zastoka iz globočin:

morda zbesnel je Aheront zaradi vdora

v njegovih strašnih brezen nedostopno temo,

morda zlomila svojo vez je Zemlja, da bi mrtve

na dan spustila; ali pa triglavi Kerber

besneč postresel svoje težke je verige.

Ta hip zazeva zemlja, neizmerno se

odpre naročje: sam sem videl jezera

otrpla sredi senc, jaz sam bogove blede

in resnično noč - zastala $\mathrm{v}$ žilah mi je kri

in zledenela. Divja vojska je pritekla,

zalega kačja, bratske trume, iz zoba

dirkajskega rojene, v polni bojni opravi.

Erinij strašni krik in slepi Bes in Groza,

vse, kar poraja večna noč in v sebi skriva:

lase si v krčih trga Žalost brez tolažbe,

Bolezen, ki le stežka dviga trudno glavo,

Starost s seboj na plečih in grozeči Strah,

in Kuga, ki Ogigov rod požira hlastno.

Zapustil me je duh. Še ona, ki pozna

očetove veščine, otrpne. Ta pa kliče,

v slepoti neustrašen, Dita krutega 
brezkrvno ljudstvo ... Kot oblaki lahni

letijo, dihajo zrak prostega neba.

$\mathrm{Na}$ vejah Eriksa ni osipljivih listov,

600

ni toliko cvetov na spomladanski Hibli,

ko gosti roj čebel se v tesno kroglo spleta,

ne lomi Jonsko morje toliko valov,

in ptic ni toliko, ki pretnja Strimona

ledenega jih $\mathrm{v}$ beg požene prek neba,

605

da snežni sever menjajo za topli Nil;

kot ljudstev, ki jih vedežev je glas priklical.

Drhteče duše hlastno iščejo zavetje

si v sencah gaja. Prvi Zetos se prikaže:

z desnico bika divjega drži za rog,

ob njem Amfíon z liro v levi roki stopa,

on, ki z milino zvokov je prestavljal skale.

In Tantalova hči med svojimi otroki naposled varna povzdiguje ošabno glavo

in šteje svoje sence. Tu je slabša mati,

Agava pobesnela: vse krdelo ji

sledi, ki kralja je razkosalo, a Bakham

sledi Pentej,raztrgan, a še zdaj preteč.

Naposled pa, po mnogih klicih, sramujoč se

povzdigne glavo, daleč proč od vseh se umika

620

in skriva (stigijske molitve vztrajno vedež

ponavlja spet in spet, dokler ne odstre

obraza) - Laj! O groza me je teh besed!

Tam stal je strašen, vsepovprek oblit s krvjo,

sršavih las, oblepljenih $\mathrm{z}$ nesnago gnusno,

625

na ustnicah žari mu bes: "O strašna hiša,

o Kadmov dom, vesel krvi sorodne zmeraj!

Vihtite tirs, naj božji bes vam vodi roke,

raztrgajte sinove: največji zločin

tebanski je - ljubiti mater. Domovina,

ne božja jeza, greh te ubija! Ni kriv južnik

zlonosni s težko sapo, niti dih sušeči

iz zemlje, ki je eter z dežjem ni potešil.

Krvavi kralj za kruti umor dobil je žezlo

in v spalnico očetovo brezbožno legel,

zavržni sin - in vendar mati je še hujša,

ker v maternici nosi spet - nesveti - plod.

V izvor se svoj je vrnil, v mater zasejal

brezbožni sad, kar komaj kdaj zveri počnejo:

zaplodil si je brate. Zlo zamotano, 
pošastnejše, bolj zapleteno kakor Sfinga!

Le tebe, kralj s krvavim žezlom, bom preganjal,

in mesto tvoje, jaz, nemaščevani oče:

s seboj Erinijo pripeljem za nevesto,

ki živžga strašne udarce $z$ bičem; grešni dom

645

porušim in $z$ brezbožno vojno strem ta rod.

Zato takoj zdaj kralja izženite iz dežele.

Naj gre, kamor že nese ga korak pogubni.

Naj zapusti ta tla: ozelenela bodo

v pomladnem cvetju; $z$ dihom, ki življenje daje,

čist zrak se vrne, vrne se lepota $\mathrm{v}$ gozd.

Poguba, Kuga, Smrt, Trpljenje, Bolečina,

Trohnoba - prava druščina - naj grejo z njim!

On hotel naglo bo zbežati iz kraljestva,

a jaz ovire težke mu postavil bom pred noge in ga ustavil. Starec negotov bo lezel, s palico tipaje bridko pot.

Vzemite mu deželo, jaz mu bom nebo!« 